(C) 2021 by the author. This work is licensed under

Creative Commons Attribution 4.0 International License

https://creativecommons.org/licenses/by/4.0/

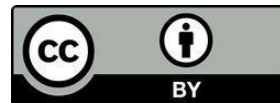

elSSN: $2708-9800$

https://doi.org/10.47316/cajmhe.2021.2.4.05

PUBLICATION ETHICS

OPINION

\title{
PERSONAL CONFLICTS OF INTEREST IN THE PUBLISHING ENTERPRISE: FOCUS ON JOURNAL EDITORS
}

Received: October 13, 2021

Accepted: October 23, 2021

\author{
Jaime A. Teixeira da Silva ${ }^{1^{*}}$ \\ ${ }^{1}$ Independent researcher, P. O. Box 7, Ikenobe 3011-2, Kagawa-ken 761-0799, Japan
}

${ }^{*}$ Corresponding author: Jaime A. Teixeira da Silva, PhD, Independent researcher, P. O. Box 7, Ikenobe 30112, Kagawa-ken 761-0799, Japan

E-mail: jaimetex@yahoo.com

\begin{abstract}
Editors play a central role and form an essential link in the publication process. Consequently, they hold considerable influence as to how the literature is molded, and what eventually gets published. In addition to their standard editorial responsibilities, holding that amount of power, editors have extremely high responsibilities to declare any conflicts of interest (COls) internal to, and external to, the peer review process, particularly those involving personal relationships and networks. This is because they also exist in the peer community, can be high-profile public figures, and form a very unique and restricted - in terms of size, membership and exclusivity - set of individuals. Consequently, editors need to declare their COls openly, transparently, and publicly on their editor board profiles, and as part of their curriculum vitae. Without such declarations, the greater risk is that editors might have unregulated freedom to enforce their own individual or group biases, through hidden relationships and networks, including the possibility of hiding instances of favoritism, cronyism and nepotism. In the worst-case scenario, this might reflect editorial corruption. Hidden COls in authors, which tend to be the focus of the academic publishing establishment, including in codes of conduct and ethical guidelines such as those by COPE and the ICMJE, tend to down-play editorial COls, or restrict them to scrutiny during the peer review process. This opinion piece examines whether there is a systemic problem with under-reported editorial COls, particularly personal and non-financial COls, that extend beyond the peer review process and their editorial positions. Greater awareness, debate, and education of this issue are needed.
\end{abstract}

Keywords: Accountability, Bias, Conflict of interest (COI), COPE/DOAJ/OASPA/WAME Best Principles, Ethics, Opacity, Relationship of interest (ROI), Transparency

How to cite: Teixeira da Silva JA. Personal conflicts of interest in the publishing enterprise: focus on journal editors. Cent Asian J Med Hypotheses Ethics 2021:2(4):215-221. https://doi.org/10.47316/cajmhe.2021.2.4.05

\section{IS THERE AN INDUSTRY-WIDE DOUBLE-STANDARD FOR EDITORIAL CONFLICTS OF INTEREST?}

Editors occupy an exclusive zone - both in terms of their status and responsibility - in academic publishing. Not only do they serve as the gatekeepers of quality control of information that they publish in their journals, with the maximum bearer of responsibility being the editor-inchief (EIC), they also serve as a management-related conduit when a publisher or society is involved [1]. It is because editors have this tremendous responsibility that they are rewarded this exclusive position, so the position should not be abused in any way to advance personal or political ideologies. Editors can use this position for career advancement, and should thus declare their editorial positions on their curriculum vitae (CVs), maintaining their $\mathrm{CV}$ s up to date, accurate, and complete [2]. Editors who are affiliated with an institution or research institute, as well as those that operate 
independently, have the responsibility of maintaining their institutional CV, social profiles and public CVs (e.g., ResearchGate, Frontiers Loop, Open Researcher and Contributor ID (ORCID), etc.) up to date, accurate, and complete [2]. Since editors serve as the academic "public relations officers" of journals and publishers, and between journals and the public and wider academic community, the accuracy of their public profile can reflect their transparency.

Why is such a high standard expected of editors, and thus their profiles, and their CVs? As was mentioned briefly above, editors not only have a peer responsibility, i.e., towards their peers and other academics in their field of research, as "experts", thus having been selected as editors, but also in public and thus society, beyond the academic, scholarly and publishing spheres. Even so, there is still a systematic absence in the academic publishing industry about how editors are selected, by whom, and with what qualifications [3]. In essence, editors are the public "face" of the journal, and thus their actions, beyond overseeing the editing and peer review of papers, are critically observed by members of the public, or should be. Since journals are intellectual assets and, in many cases, financial assets or tradeable commodities, either through subscriptions or article processing charges (APCs) in open access publishing, editors also carry - whether they are aware of this, or not - intellectual and financial responsibilities. Consequently, when editors serve as such for different journals, even more so when those journals are published by different and "competing" publishers, i.e.that is, publishers that compete for a slice of a similar intellectual or publishing market, they have the responsibility of indicating these "competing" positions and relationships not only on their CVs, social media and institutional web pages, but also on the pages of the journals' editor boards. The failure to declare these "competing" positions and relationships - even if they are not financially motivated - is equivalent to a hidden disclosure and thus hidden conflict of interest (COI) [4]. This includes personal relationships, networks or relationships with groups, action groups, think tanks, policy groups, philanthropies or any other ideologically distinct group, financial or non-financial, that may be an actual or perceived relationship of interest (ROI). An ROI thus becomes a category of $\mathrm{CO}$ if they are undeclared. Undeclared editorial COls, including ROls, are considered to be a form of misconduct [5].

\section{AN APPRECIATION OF EDITORIAL NON-FINANCIAL CONFLICTS OF INTEREST}

What is a non-financial COI, or ROI? PLOS (Public Library of Science), which is a Committee on Publication Ethics (COPE) member, offers a useful list of financial and non-financial COls that provides an initial introduction to this topic [6]. PLOS considers COls to be financial (e.g., owning stocks/shares, paid employment, consultancy, membership of boards, patents, research and travel grants, gifts) and non-financial (e.g., expert witnesses, members of a government or advisory board, any relationship with non-state organizations, research institutions, or charities, members of lobbying or advocacy groups, writing or editorial consultancy, personal or professional relationships, and personal convictions) [6]. Non-financial COls might also be perceived to be views, experiences, beliefs, or relationships [7], the latter collectively referred to as ROls in this paper. Finally, editorial non-financial COls may be academic, that is, evaluation of grants, scientific communications, including the creation and development of guidelines, lectures, advisory roles, decision-making, teaching, and mentoring [8]. Consequently, by definition, if an editor fails to declare any of these in their capacity as an editor, that is, within their editorial duties and as public representatives of the journal and public, they are in essence hiding COls and ROls. When COls are hidden, unintentionally or willfully, they reflect badly on the academic and ethical standing of the ethical and biomedical communities [9].

In many industry-wide ethical guidelines pertaining to COls, such as those by the International Committee of Medical Journal Editors (ICMJE) [10], COPE [11], and many other medical organizations, ROls are not often discussed separately, and may appear bracketed under non-financial COls [12]. However, unlike PLOS, the COls described by groups such as the ICMJE or COPE primarily target authors, and to a more limited extent editors, but only in a limited framework, namely, their relationships with other editors and authors within the peer review process. Such COI-related ethical guidelines serve primarily to "call out" authors who might be in violation of a COI, for example, hiding a COI (e.g., industry link), particularly when their paper's COI statement indicates that they have no COls to declare.

Conversely, editors, who are rarely named in published papers, do not have to make such written/published statements, and are thus not held to the same level of scrutiny as authors in terms of actual, perceived and hidden COls. Or are they? Two recent examples in 
COPE member journals and publishers (Elsevier) call out editors who failed to declare their editorial positions in published papers within the same journal in which they serve as editors or EICs $[13,14]$. This indicates that other editors or EICs who have published papers in COPE or ICMJE member journals and publishers might also need to retrospectively correct their papers. Even so, this failure of editors and EICs to declare COls is within the realm of their editorial duties within the confines of their journal, and not more broadly (peer community, public) being discussed in this paper, but important to point out nonetheless.

In an academic publishing landscape clamoring for greater transparency and accountability, it should not be acceptable that editors be held to a different (lower) level of standards (in terms of COls and ROls) than authors, even more so, given their elevated hierarchy in the publishing chain of command. If anything, editors should be held to the highest standards of scrutiny in biomedicine [9]. If an author fails to declare a relevant $\mathrm{COI}$ or ROI, this may be perceived as a hidden $\mathrm{COI}$, and in some extreme cases, these may result in the retraction of a paper, an expression of concern, or, if considered as a "minor" issue, an erratum. If authors are held to such strict and high ethical standards, should editors also not be held to the same, if not higher, ethical standards? Despite this glaringly obvious double standard in academic publishing, why does it seem that editors are offered such "protection" by the publishing establishment $[5,12]$ ?

One possible reason may be that editors and EICs are precious commodities to journals and publishers, that is, without editors and EICs, publishers have no mechanism to exploit authors, authors' institutes and authors' funding agencies for intellect, subscriptions and APCs. Consequently, there is a subtle, unspoken industry-wide COI, namely, the "protection" of editors and EICs by publishers, thereby allowing the "exploitative" model of publishing, including free service by peer reviewers and editors, to thrive [15]. If a hidden $\mathrm{COI}$ is ethically unacceptable, then why do publishers and the peer community tend to look the other way when editors fail to declare financial and non-financial COls? Why is it rare, almost impossible, to find editor boards with up-to-date CVs and financial and non-financial COI declarations for their editors? Even though awareness has been raised about this serious double-standard in the publishing industry, even among highly ranked and "respected" status quo journals and publishers $[4,5,12,15,16,17]$, the predominant model continues to be that editors do not carry COI statements alongside their names on a journal's editor board. In contrast, it is not uncommon for authors to have to submit, as a mandatory requirement for submission of a paper to a journal, a COl statement, in several cases using the template provided by the ICMJE. This double ethical standard, one for authors and another for editors, should be considered unacceptable and must be urgently reformed. Curiously, this important issue was not covered in a historical description of the changes to the ICMJE's recommendations [18].

\section{RISKS TO ACADEMIA OF COI-BASED EDITORIAL DOUBLE STANDARDS}

Based on these arguments, in the author's view, it is unacceptable for journals and publishers to preach messages of transparency, openness, and author and/or editor responsibility pertaining to COls but then exclusively threaten authors with sanctions and severe penalties and consequences if they violate ethical guidelines they are supposed to follow (e.g., by COPE, ICMJE, etc.) while maintaining a separate standard of scrutiny for their own journal members' editors. Another possible reason for the existence of an entrenched industry-wide double ethical standard at the level of editorial COls is because bodies such as the COPE, while providing "ethical guidelines" for the industry, also serve as an industry "ethics" branding service, making COPE membership part of an "exclusive" club. Consequently, there is an apparent intrinsic bias in the treatment of editors within the current academic publishing industry, and COPE member journals and publishers (to a lesser extent, ICMJE, because there is no financial cost to becoming an ICMJE member). The author has already expressed concerns about possible hidden financial and non-financial COls that involve COPE and select "groups" within the scientific community [19]. Curiously, since few in academia are paying attention to this issue, it is the responsibility of academic societies, rather than industry-influenced policy groups, to raise awareness, increase discussion, and establish new ethical guidelines that serve the entire academic community [20].

The existence of this double standard indicates that there is currently an industry-wide level of ethical exceptionalism [21], that is, one (higher) level of ethics for authors who are exploited but who are replaceable, and a separate (lower) level of ethics for editors (representing publishers' interests), who are also exploitable but a more valuable sometimes irreplaceable commodity because they ensure the constant flow of a publisher's intellect, subscriptions, APCs, etc. Ultimately, many editors are researchers (and authors) themselves, so why should they receive preferential ethical treatment? 
Concerned that some ethically-preaching editors in prominent positions of power and influence may be unwilling to concede to the existence of this industrywide ethical double standard, this paper sets out to establish a platform for discussion of financial and nonfinancial COls and ROls that editors might have but that should be declared, not only in their CVs and institutional profiles, but also on editorial web pages.

\section{WHAT PARAMETERS DEFINE AN EDITORIAL NON-FINANCIAL CONFLICT OF INTEREST?}

Assuming that the rules of engagement for authors and editors are equal, and thus fair, and considering that authors and editors are often mixed in an entangled web of relationships within their peer communities and beyond, this section aims to highlight the financial and non-financial relationships that are, or could be construed, as a COI or ROI. The PLOS guidelines for COls [6] already spell out several categories succinctly, but some of these are expanded upon next, for clarity.

At first, editors whose "spouses (husband, wife, legal partner) or kin (family member or relation)" are coauthors or share editorial positions on the same or different editor board, should be clearly indicated in their CVs and editorial profiles, "whether they share the same or have separate family names" [22]. As was argued in that paper, such positions could lead to ideological, intellectual or even practical (financial and non-financial) bias or influence (e.g., related to papers, projects, funding, collaborations, etc.). Similarly to spouses and kin, the following relationships between individuals could be perceived as COls and ROls (within a 5- to 10-year window): collaborators (papers, projects, etc.), coauthors, networks (groups, institutes, organizations, associations, committees, policy groups, funding agencies, etc.), political and religious affiliations, media interaction, etc. Even though a 5- to 10-year moratorium is suggested, this could be retroactively applied. For example, if an editor in a COPE member journal 10 years ago had any COls or ROls, within the preceding 5- or 10year window, but failed to declare such COls or ROls, then an erratum would be forthcoming and necessary, as exemplified by two recent cases $[13,14]$.

This is why publishers have the responsibility of recording and archiving (i.e., indexing) the changes in editorial boards of journals, even of journals that they no longer publish, because such lists and information constitute an essential part of the journal's history, bearing both a scholarly and ethical weight. Moreover, when editors are removed, the publisher also has the responsibility to record such removals formally, either as an editorial note, or as a publisher's note. The journal's EIC should be responsible for overseeing the accuracy of the archival of the editor board's record. The author is also of the opinion that the "silent" removal of editors from editor boards, for example as a result of a scandal or unethical behavior of editors, constitutes unscholarly and possibly predatory behavior on the part of journals and publishers that engage in such opaque actions. To the author's knowledge, this topic is rarely discussed in the academic literature, but merits greater scrutiny and debate.

In all cases, such relationships could affect the objectivity of the editors, and their functions as editors, either in relation to the handling of papers (e.g., intellectual bias for or against submissions), or in how the journal serves not as an intellectual channel of discovery, but more as a policy-implementing vehicle of influence. In other words, by "secretly" selecting editors who are somehow related (family, kin, collaborators, ideological groups, etc.), without publicly, openly and transparently indicating how they were elected, that is, opacity and secrecy might actually indicate favoritism, cronyism and/or nepotism [17], particularly if such editors are individuals of power, influence, or reputation. Consequently, when editors who hide their COls are banded together, they may form a formidable "power body" that gives the impression of a reputable editor board whereas, in fact, under the surface, individual editors or collectively, they may be serving to advance a larger ideology, or pushing an academic or political agenda. If the process by which an editor is selected to an editor board is not transparently and openly revealed to the public and peer community [3], and if collaborating editors are found to exist on the same editor board, but are not declared as such, then these are hidden financial or non-financial COls and ROls, and thus constitute serious ethical infractions and professional violations of established codes of conduct, that is, favoritism, cronyism and nepotism [17].

Currently, the author is of the belief that mainstream (e.g., COPE, ICMJE, etc.) ethical guidelines offer ethical "protection" to editors, particularly among member journals and publishers, because editors play a vital exploitative role in academic publishing, keeping in mind that most editors work voluntarily to attract intellect and thus derive intellect and/or profit for a journal or publisher. In addition, many editors in such organizations are medical editors, who have functions in the academic community not only as authors and editors, but also as policy makers. Moreover, there is also an abundance of medical editors doing editing work for editing companies. 
In the latter case, when the work of editors for editing companies is hidden from their profiles and $\mathrm{COI}$ statements, this constitutes an extremely serious hidden financial $\mathrm{COI}$ and ethical violation, for example, according to the ICMJE and PLOS, similarly to authors who fail to declare, in the acknowledgements of their papers, the use of such editing services [23].

Hidden COls by editors, whether these be financial or non-financial, erode trust in the academic and editorial establishments, breed mistrust, and lead to abuses of power $[9,17,24]$. Consequently, comprehensive education about these issues is needed by ethics- conscientious editors as well as organizations such as the COPE, ICMJE, and other ethics-related biomedical organizations [12] that create guidelines and rules for academic publishing related to COls.

\section{CONFLICTS OF INTEREST}

The author declares no relevant financial or non-financial conflicts of interest related to this topic. However, in several published papers, the author has offered an academic discussion about some of the organizations mentioned in this paper.

\section{REFERENCES}

1. Dobránszki J, Teixeira da Silva JA. Editorial responsibilities: both sides of the coin. J Educ Soc Res 2016;6(3):910.

2. Teixeira da Silva JA, Dobránszki J, Al-Khatib A, Tsigaris P. Curriculum vitae: challenges and potential solutions. KOME 2020;8(2):109-127.

3. Teixeira da Silva JA, Al-Khatib A. How are editors selected, recruited and approved? Sci Eng Ethics 2017;23(6):1801-1804.

4. Teixeira da Silva, JA. Conflicts of interest arising from simultaneous service by editors of competing journals or publishers. Publications 2021;9(1):6.

5. Green LS, Johnston MP. A contextualization of editorial misconduct in the library and information science academic information ecosystem. J Assoc Inf Sci Technol 2021 (in press). https://doi.org/10.1002/asi.24593

6. Public Library of Science (PLOS). (2021). Competing Interests. https://journals.plos.org/plosone/s/competinginterests. Last accessed: October 23, 2021.

7. Grundy Q, Mayes C, Holloway K, Mazzarello S, Thombs BD, Bero L. Conflict of interest as ethical shorthand: understanding the range and nature of "non-financial conflict of interest" in biomedicine. $\mathrm{J}$ Clin Epidemiol 2020;120:1-7.

8. Annane D, Lerolle N, Meuris S, Sibilla J, Olsen KM. Academic conflict of interest. Intensive Care Med 2019;45(1):13-20.

9. Wiersma M, Kerridge I, Lipworth W. Dangers of neglecting non-financial conflicts of interest in health and medicine. J Med Ethics 2018;44(5):319-322.

10. International Committee of Medical Journal Editors (ICMJE). (2021). Disclosure of interest. http://icmje.org/disclosure-of-interest/. Last accessed: October 23, 2021.

11. Committee on Publication Ethics (COPE). (2021). Conflicts of interest / Competing interests. https://publicationethics.org/competinginterests. [Accessed 23 Oct 2021]

12. Grundy Q, Mazzarello S, Bero L. A comparison of policy provisions for managing "financial" and "non-financial" interests across health-related research organizations: A qualitative content analysis. Account Res 2020 (in press). https://doi.org/10.1080/08989621.2020.1748015

13. Houck MM, Horsman G, Sauzier G, Bidmos M. Erratum to "What is open-access publishing and what it means for the forensic enterprise" [Forensic Sci. Int.: Synergy (2019) 290-293]. For Sci Int Synergy 2020;2:708.

14. Hernández AF, Calina D, Poulas K, Docea AO, Tsatsakis AM. Erratum to "Safety of COVID-19 vaccines administered in the EU: Should we be concerned?" [Toxicol. Rep. 8C (2021) 871-879/1111]. Toxicol Rep 2021 (in press). https://doi.org/10.1016/j.toxrep.2021.08.011

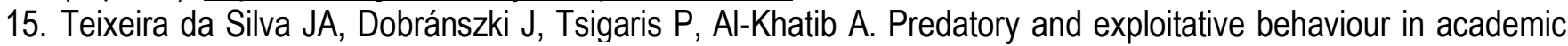
publishing: An assessment. J Acad Librariansh 2019;45(6):102071.

16. Teixeira da Silva JA, Dobránszki J, Bhar RH, Mehlman CT. Editors should declare conflicts of interest J Bioeth Inq 2019;16(2):279-298. 
17. Teixeira da Silva JA, Katavić V, Dobránszki J, Al-Khatib A, Bornemann-Cimenti H. Establishing rules for ethicists and ethics organizations in academic publishing to avoid conflicts of interest, favoritism, cronyism and nepotism. KOME 2019;7(1):110-125.

18. Kojima T. Disclosure of potential conflicts of interest in biomedical publications in view of the International Committee of Medical Journal Editors recommendations. Cent Asian J Med Hypotheses Ethics 2021;2(1):18-22.

19. Teixeira da Silva JA. Debunking the loss of the Committee on Publication Ethics (COPE) moral compass: conspiracy theory, or genuine cause for concern? Eubios J Asian Int Bioeth 2019;29(3):99-109.

20. Gasparini M, Tarquini D, Pucci E, Alberti F, D'Alessandro R, Marogna M, Veronese S, Porteri C, Bioethics and Palliative Care Study Group of the Italian Neurological Society. Conflicts of interest and scientific societies. Neurol Sci 2020;41(8):2095-2102.

21. Teixeira da Silva JA. Ethical exceptionalism: can publishing rules be manipulated to give the impression of ethical publishing? Bangladesh J Med Sci 2017;16(4):610-614.

22. Teixeira da Silva JA, Rivera H. Spousal and kinship co-authorship should be declared to avoid conflicts of interest. J Bioeth Inq 2021; 18(4) (in press). https://doi.org/10.1007/s11673-021-10123-1

23. Teixeira da Silva JA. Outsourced English revision, editing, publication consultation and integrity services should be acknowledged in an academic paper. J Nanoparticle Res 2021;23(4):81.

24. Marušić A. Editorial interest in conflict of interest. Croat Med J 2009;50(4):339-341. 


\section{БАСЫЛЫМДАРДЫ ЖАРИЯЛАУ БАРЫСЫНДАҒЫ МУДДЕЛЕР ҚАЙШЫЛЫҒЫ: ЖУРНАЛ РЕДАКТОРЛАРЫНА НАЗАР АУДАРУ}

\section{Түйіндеме}

Редакторлар басты рөл атқарып, жариялау процесінің маңызды буыны болып табылады. Сондай-ақ, олар әдебиеттердің қалыптасуына да және нәтижесінде не жарияланатынына да елеулі ықпал етеді. Осындай өкілеттіктерге ие бола тұра, редакторлар кез-келген мүдделер қақтығысын, әсіресе жеке қатынастармен байланысты жанжалдарды жариялауға жауапты. Бұл олардың танымал қоғам қайраткерлері бола алатындығымен және ерекше әрі шектеулі адамдар тобын құрайтындығымен түсіндіріледі. Сонымен, редакторлар өздерінің мүдделер қақтығысын өмірбаяндық мәліметтердің бөлігі ретінде редакциялық кеңес пішіндерінде ашық, таза және көпшілікке жариялауы керек. Мұндай мәлімдемелерсіз редакторлардың реттелмейтін бостандыққа ие болуы және жасырын байланыстар мен желілер арқылы жеке немесе топтық теріс қылықтарды қолдануы, сондай-ақ фаворитизм мен непотизм жағдайларын жасыруы мү мкін тә уекелі бар. Ең болмағ анда бұл редакциялық сыбайлас жемқорлыққа әкелуі мүмкін. Академиялық баспа мекемесінің, соның ішінде COPE және ICMJE сияқты мінез-құлық кодекстері мен этикалық принциптердің назарында болатын авторлардың жасырын мүдделер қақтығысы, әдеттегідей, редакторлық мүдделер қақтығысының мағынасын төмендетеді немесе оларды мұқият тексерумен шектейді. Бұл жұмыста редакторлардың, әсіресе рецензиялау процесінің шеңберінен тыс жеке және қаржылық емес мүдделердің мүдделер қақтығысын хабарлау үшін жүйелік мә селенің бар-жоғы зерттеледі. Қарастырылған мәселе бойынша кеңінен хабардарлық, талқылау және ағарту қажет екендігі анықталды.

Түйінді сөздер: есеп берушілік, біржақтылық, мүдделер қақтығысы, COPE/DOAJ/OASPA/WAME қағидалары, этика, ашық еместік, мүдделердің өзара байланысы, ашықтық

Дәйексөз үшін: Тейшейра да Силва Ж.А. Басылымдарды жариялау барысындағы мүдделер қайшылығы: журнал редакторларына назар аудару. Медициналық гипотеза мен этиканың Орта Азиялық журналы. 2021:2(4):215-221. https://doi.org/10.47316/cajmhe.2021.2.4.05

\section{КОНФЛИКТЫ ИНТЕРЕСОВ В ПРОЦЕССЕ ИЗДАНИЯ ПУБЛИКАЦИЙ: ФОКУС НА РЕДАКТОРОВ ЖУРНАЛА}

\section{Резюме}

Редакторы играют центральную роль и являются важным звеном в процессе публикации. Они оказывают влияние и на то, как и в каком виде размещается публикация. Обладая такими полномочиями, редакторы ответственны за декларирование любых конфликтов интересов, особенно тех, которые связаны с личными отношениями. Это объясняется тем, что они могут быть известными публичными фигурами и составляют уникальный и ограниченный по численности коллектив людей. Следовательно, редакторы должны декларировать свои конфликты интересов открыто, прозрачно и публично в своих профилях редакционных советов как часть биографических данных. Без таких заявлений риск состоит в том, что редакторы могут иметь нерегулируемую свободу и навязывать свои личные или групповые предубеждения через скрытые связи и сети, а также иметь возможность сокрытия случаев фаворитизма и кумовства. В худшем случае это может привести к редакционной коррупции. Скрытые конфликтов интересов у авторов, которые, как правило, находятся в центре внимания академического издательского учреждения, в том числе в кодексах поведения и этических принципах, таких как СОРЕ и ICMJE, как правило, принижают значение редакционных конфликтов интересов или ограничивают их внимательной проверкой. В данной работе исследуется, существует ли системная проблема несообщения конфликтов интересов редакторов, особенно личных и нефинансовых интересоы, которые выходят за рамки процесса рецензирования. Было выявлено, что необходимы широкая осведомленность, обсуждение и просвещение по рассмотренному вопросу.

Ключевые слова: подотчетность, предвзятость, конфликт интересов, принципы COPE / DOAJ / OASPA / WAME, этика, непрозрачность, взаимосвязь интересов, прозрачность

Для цитирования: Тейшейра да Силва Ж.А. Конфликты интересов в процессе издания публикаций: фокус на редакторов журнала. Центральноазиатский журнал медицинских гипотез и этики. 2021:2(4):215-221. https://doi.org/10.47316/cajmhe.2021.2.4.05 